\title{
geosciences
}

ISSN 2076-3263

www.mdpi.com/journal/geosciences

Article

\section{Geodynamic Reconstructions of the Australides-1: Palaeozoic}

\section{Christian Vérard and Gérard M. Stampfli *}

Institute of Earth Science, University of Lausanne, Géopolis, Quartier Mouline, Lausanne CH-1015, Switzerland; E-Mail: xian_verard@hotmail.com

* Author to whom correspondence should be addressed; E-Mail: gerard.stampfli@unil.ch; Tel.: +41-21-692-4306; Fax: +41-21-692-4305.

Received: 23 March 2013; in revised form: 29 April 2013/Accepted: 13 May 2013/

Published: 4 June 2013

\begin{abstract}
A full global geodynamical reconstruction model has been developed at the University of Lausanne over the past 20 years, and is used herein to re-appraise the evolution of the Australides from 600 to 200 Ma. Geological information of geodynamical interest associated with constraints on tectonic plate driving forces allow us to propose a consistent scenario for the evolution of Australia-Antarctica-proto-Pacific system. According to our model, most geodynamic units (GDUs) of the Australides are exotic in origin, and many tectonic events of the Delamerian Cycle, Lachlan SuperCycle, and New England SuperCycle are regarded as occurring off-shore Gondwana.
\end{abstract}

Keywords: Australia; Antarctica; Gondwana; Gondwanides; Australides; Palaeozoic; plate tectonics; geodynamic reconstructions

\section{Introduction}

The geodynamic history of the Australides (termed after [1]) throughout the Phanerozoic is a matter of debate, in particular concerning the origin of "terranes" (see, for instance, discussion from a palaeomagnetic point-of-view synthesized in [2]; and from a geological point-of-view synthesized in [3]), and therefore, the interaction between the East Gondwana margin and the vast realm often included under the name "Panthalassa Ocean" (e.g., [1]).

The present work aims to reappraise the geodynamic evolution of the East Australia-East Antarctica-Tasman Sea-New Zealand-proto-Pacific region for the Palaeozoic-and for the Mesozoic-Cainozoic in a companion paper [4] - from a full global reconstruction model. The model is 
merely a model, but uses strict plate tectonic rules and physically coherent hypotheses, deeply rooted on geological data. Although many hypotheses were tested during the development phase of the model, the degree of freedom is revealed to be low when the model must comply at global scale with all geological data, with plate kinematics and plate geometries, and with geodynamic scenarios. The model presented herein takes into account as many of these constraints as possible.

The discussed region is a key location for understanding the evolution of the Australides. Several excellent works have addressed the tectono-stratigraphic relationships between various provinces (e.g., [5-11]) and the palaeogeography of the region (e.g., [12-15] or [16]). Tectonic and geodynamic scenarios, however, have been proposed at relative local scale (in particular for the formation of the Lachlan Orogen; e.g., [17-21]) and the "Panthalassa realm" is often left blank.

\section{Method}

A full global, physically consistent, ArcGIS ${ }^{\circledR}$-based geodynamical model covering over 600 million years (Ma) has been in development at the University of Lausanne for many years. The techniques and definitions used to create the model were partly presented in many publications (in particular [22,23] and $[24,25]$ ), and will be soon further detailed elsewhere. Here we summarize the key criteria:

(1) All tectonic plates are rigid to first order and must have closed boundaries, following the "dynamic plate boundaries approach" [22]. Synthetic ocean spreading axes, in particular, are reconstructed for time $t_{\mathrm{A}}$, and used as isochrons (or "synthetic magnetic anomalies") at time $\mathrm{t}_{\mathrm{B}}$. Where available (i.e., in particular not for the Palaeozoic), tectonic plates are positioned one relative to another using magnetic anomalies as defined by [26,27]. Isochrons (synthetic or not) are important features of the reconstructions since they constrain plate geometries, and therefore, plate kinematics. Plate velocity is defined as "acceptable" up to $22 \mathrm{~cm} /$ year (which correspond to the present-day rotation rate of the Rivera plate; $1.9781^{\circ} / \mathrm{Ma}$ or equatorial velocity of $21.99 \mathrm{~cm} /$ year after [28]).

(2) The model is "geodynamic" in the sense that it is kinematically constrained on the entire sphere in 2D, but also in 3D with scenarios accounting for forces acting at plate boundaries. These scenarios are validated a posteriori by numerical simulations (e.g., [29]), and independent datasets such as tomography images (e.g., [30,31]).

(3) Crustal fragments are defined as what we term GeoDynamical Units (GDUs) in the present-day configuration, in order to avoid misunderstanding with other terms such as continental blocks, microcontinents or terranes. GDUs are defined all over the globe (>1000 GDUs) as not deformable in order to enable geological information to be transferred back in the past, in its genuine configuration, and to test whether those data are compatible with what the model predicts ([24,25]). Consequently, non-rigid deformation such as geological bending, stretching or shortening is not corrected within a GDU, but tight/untight fits are used not to underestimate crustal extension/shortening.

(4) Differences between continental and oceanic region are related to the nature of the crust and not to shore line associated with sea-level. Present-day coast lines, of course, are shown as geographical references only.

(5) Reconstructions are global, and are made in a Europe fixed reference frame, using all possible data of geodynamical interest, which have been compiled in the PaleoDyn Database (see [24]). A palaeomagnetic grid is, however, shown on our maps, and the "pseudo-absolute" position is 
constrained using palaeomagnetic information and palaeoclimatic indicators. The apparent polar wander path (APWP) modified after [32], in particular, is used to define the "pseudo-absolute" reference frame over $600 \mathrm{Ma}$-named "pseudo" because APWPs give no constraint on palaeo-longitude. The model comprises 48 reconstructions over 600 Ma every 5 to $20 \mathrm{Ma}$.

\section{Geodynamic Reconstructions}

A "good" fit for Gondwana at about $200 \mathrm{Ma}$ is a key feature for understanding both the Palaeozoic and Mesozoic-Cainozoic evolution of the Australides. The retained solutions for the "Gondwana best-fit" are given in [4]. The position of GDUs at 200 Ma has influence on our starting configuration at $600 \mathrm{Ma}$. Note that names of GDUs are provided on this configuration (Figure 1) for readers who are familiar with the region, but, for sake of clarity, only names of large scale terranes are shown in the reconstructions (Figure 2).

Among all the work on the Australides, nomenclature and GDU definition (Figure 1) refer largely to the thorough synthetic work of [3] and numerous references therein.

Figure 1. (a) Present-day configuration (000 Ma) showing GDUs with ETOPO1 as background (topography/bathymetry of the bedrock (ice removed); [33]). Abbreviations are as in (b), except for: AS, Auckland Spur; Fio. and Rise, Campbell Fiordland and Campbell Rise; N, Norfolk Ridge; N.-Z., New Zealand; NC, New-Caledonia Ridge; NEO, New England Orogen; NVL, Northern Victoria Land. In Green are names of Australian cratons, with Yilgarn, Pilbara, Grawler, Curnamona-Broken Hill [C.-BH] and the North Australian [N.Aus] cratons (comprising Kimberley, Tanami, Mount Isa, Tennant Creek [TC], and Pine Creek cratons). (b) Reconstruction at $200 \mathrm{Ma}$ ("Gondwana Fit"). Abbreviations are provided in the figure note. Orthographic projections; this figure is in part derivative from the Neftex Geodynamic Earth Model, (c) Neftex Petroleum Consultants Ltd. 2011.

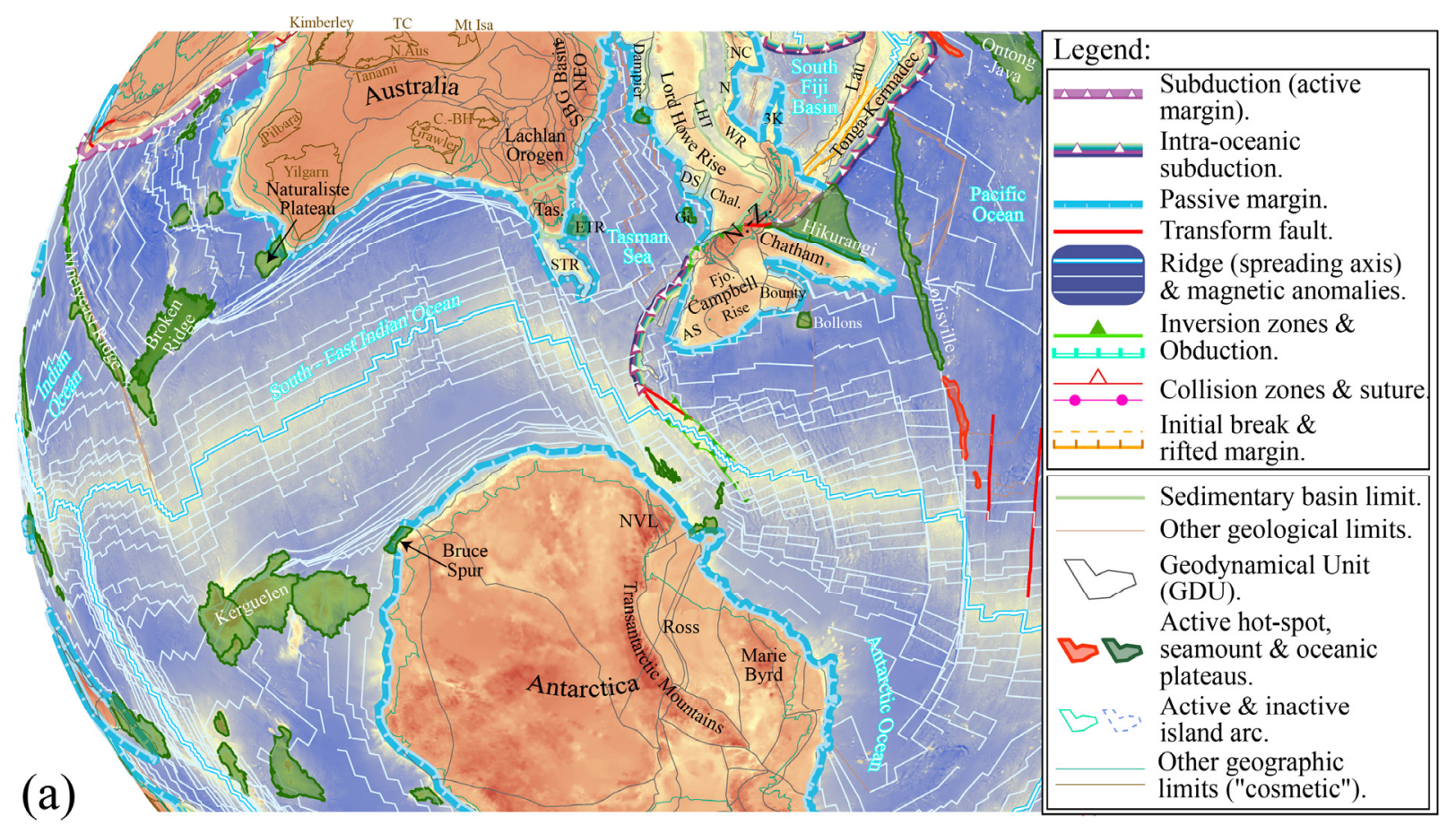


Figure 1. Cont.

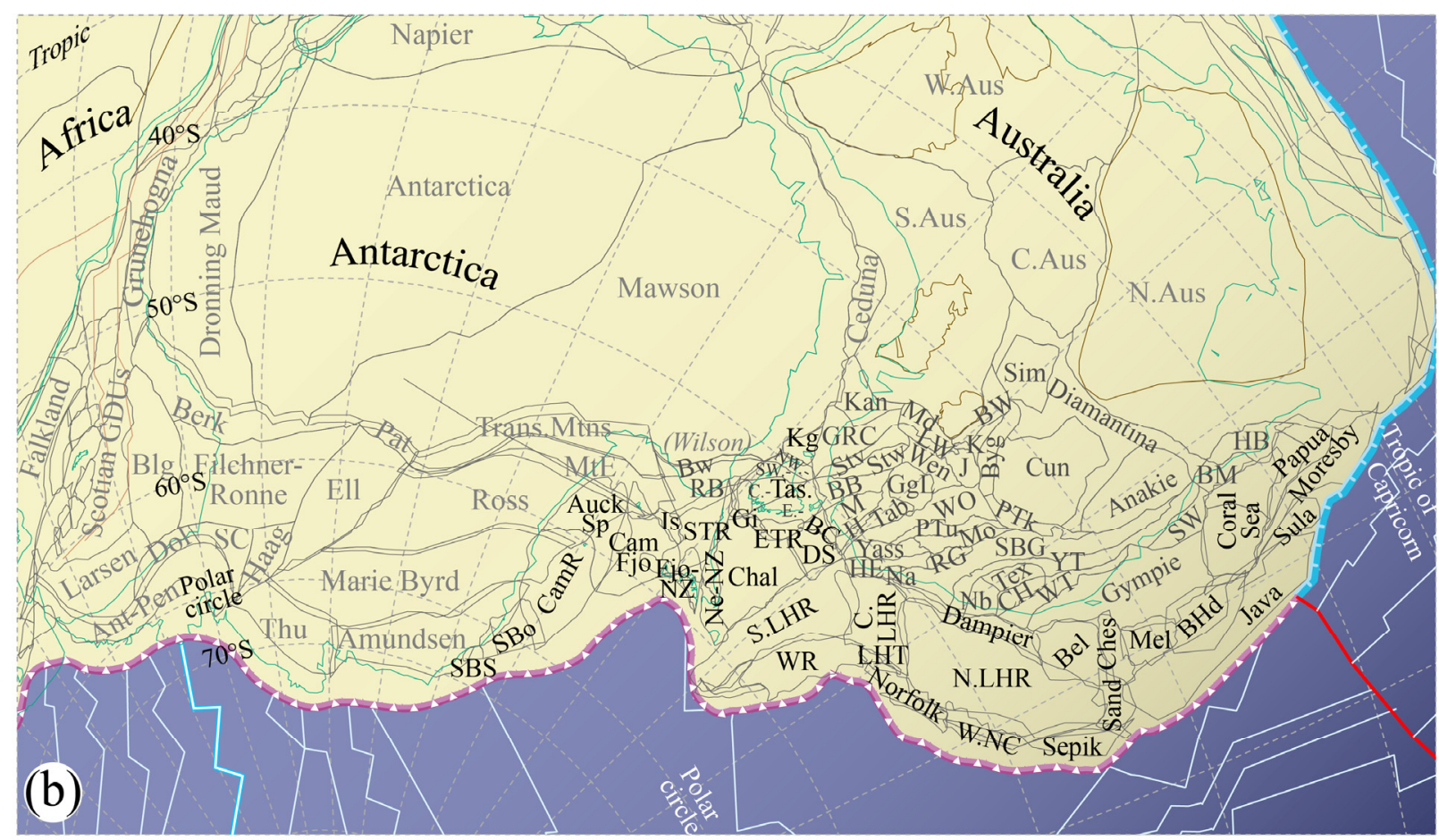

Notes: Ant-Pen, Antarctic Peninsula; Auck.Sp, Auckland Spur; BB, Bendigo-Ballarat; BC, Bass Canyon; Bel, Bellona Plateau; Blg, Belgrano; Berk, Berkner Island; BHd, Bird's Head; BM, Barnard Metamorphics; BW, Bencannia-Wertago; Bw, Bowers; Byg, Bygrave; C.Aus, Central Australia; C.LHR, Central Lord Howe Rise; CamFio, Campbell Fiordland; CamR, Campbell Rise; CH, Coffs-Harbour; Chal, Challenger Plateau; Ches, Chesterfield Plateau; Cun, Cunnamulla; Dol, Dolleman; DS, Dolphin Spur; Ell, Ellsworth Mountains; ETR, East Tasman Rise; Fio.-NZ, Fiordland province of New Zealand, comprising South Buller terrane, South Takaka terrane, and the future South Median Tectonic Zone (MTZ); GgL, Garnpung Lake; Gi, Gilbert Seamount Complex; GRC, Glenelg River Complex; H, Howqua; HB, Hogdkinson-Broken Ridge; HE, Hill-End; Is, Iselin Bank; J, Mount Jack; K, Kayrunnera; Kan, Kanmantoo; Kg, King Island; LW, Lake Wintlow; M, Melbourne; Md, Menindee; Mel, Mellish Rise; Mo, Molong; MtE, Mount Erebus; Na, Narooma; N.Aus, Northern Australia; N.LHR, North Lord Howe Rise; Nb, Nambucca; Ne.-NZ, Nelson province of New Zealand, comprising North Buller terrane, and North Takaka terrane; Pat, Patuxent; PTk, Paka Tank; PTu, Parkes-Tumut; RB, Robertson Bay; RG, Rockeley-Gulgong; S.Aus, Southern Australia; S.LHR, South Lord Howe Rise; Sand, Sandy Island; SBG, Sydney-Bowen-Gunnedah Basin System; SBo, South Bounty Plateau; SBS, South Bollons Seamount; SC, Schlossbach Cape; Sim, Simpson; STR, South Tasman Rise; Stv, Stavely; Stw, Stawell; SW, Shoal Water; Tab, Tabberabbera; Tas., Tasmania, comprising NW-, north-western Tasmania, SW-, south-western Tasmania, C-, central Tasmania, E-, eastern Tasmania; Tex, Texas; Thu, Thurston Island; Trans.Mtns, Transantarctica Mountains; W.Aus, Western Australia; W.NC, Western New-Caledonia Ridge; Wen, Wentworth; WO, Wagga-Omeo; WT, Wandilla-Tablelands; YT, Yarrol-Tamworth. 
Figure 2. Geodynamic reconstructions from (a)-(e) Middle Ediacarian to Early Cambrian; (f)-(g) Middle Cambrian to Middle-Late Ordovician; (k)-(o) Early Silurian to Middle-Late Devonian; (p)-(t) Late Devonian to Late Carboniferous; (u)-(y) Early Permian to Late Triassic. Same legend as per Figure 1. Views from the present-day South Pole, with palaeomagnetic grid (grey dashed line, $10^{\circ}$ spacing, modified after [31]). Approximate location of cross-sections of Figure 3 are shown for indication. Blue and brown background colors represent oceanic and continental lithosphere, and not the shore-line (no palaeo-geography). Present-day shore-line (turquoise) is shown as geographic indicator only. Orthographic projections; this figure is in part derivative from the Neftex Geodynamic Earth Model, (C) Neftex Petroleum Consultants Ltd. 2011. Chronostratigraphic terms after the International Chronostratigraphic Chart-version 2013/01 of the International Commission on Stratigraphy [34].

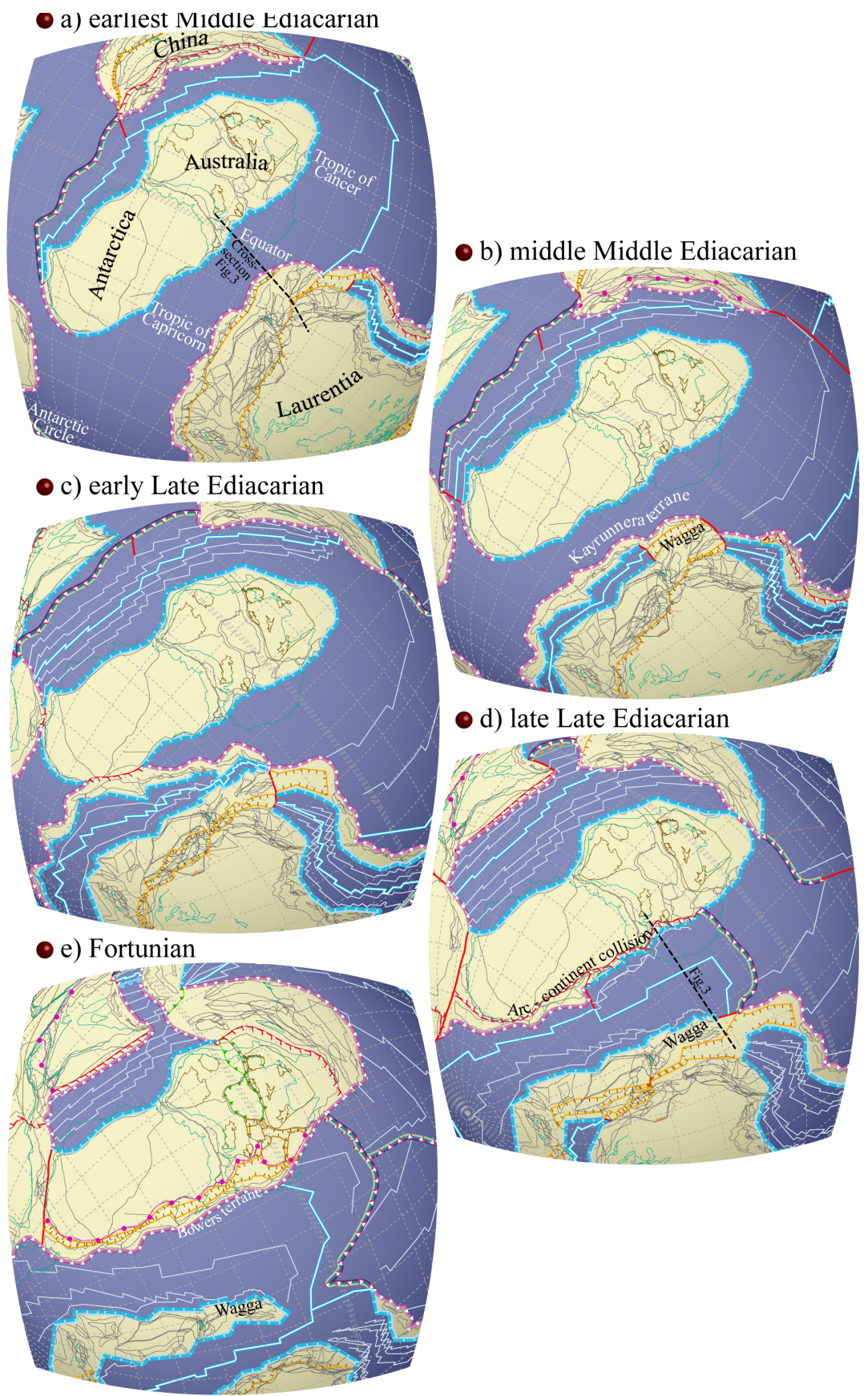


Figure 2. Cont.

- 1) Lambrian - stage 5

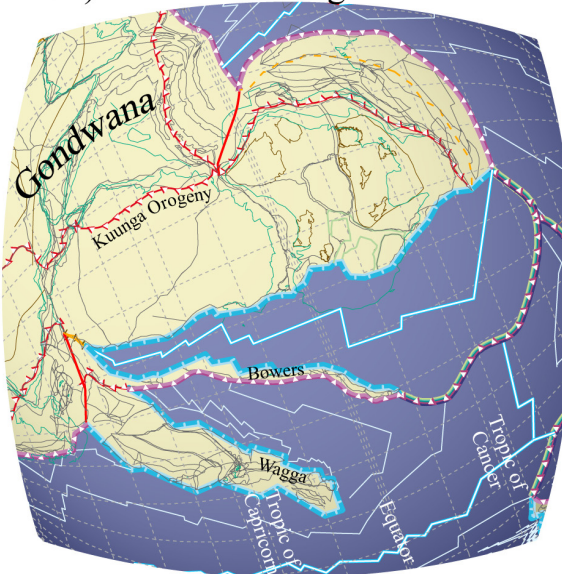

- h) Cambrian - Stage 10

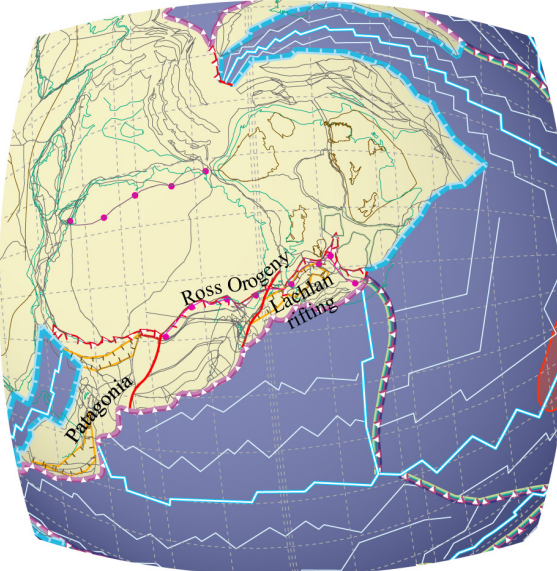

- g) Drumo-Guzhangian

• j) Darriwilian
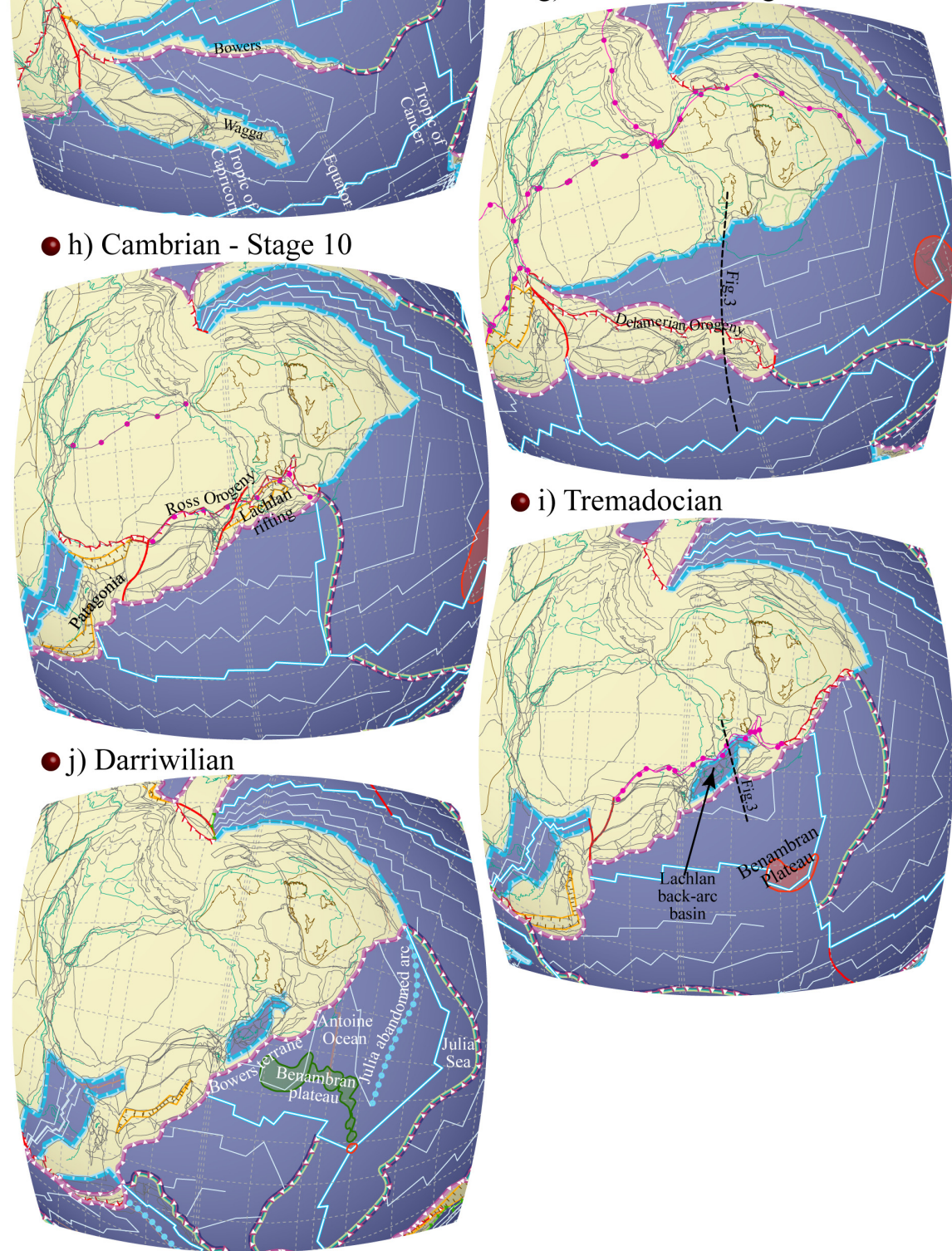

- i) Tremadocian

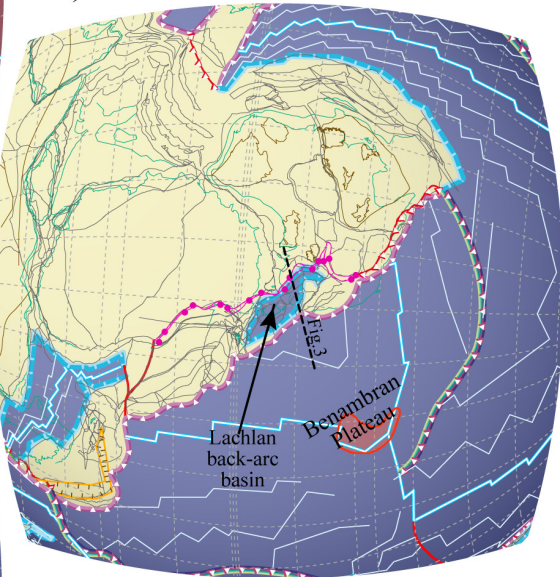


Figure 2. Cont.

- k) Rhuddanian

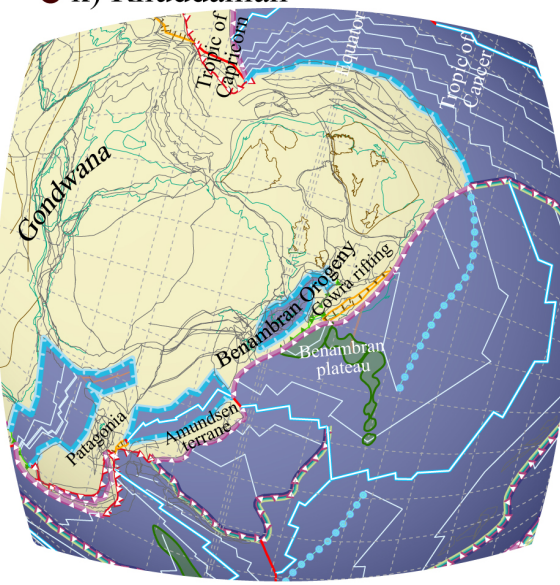

- m) Prago-Emsian

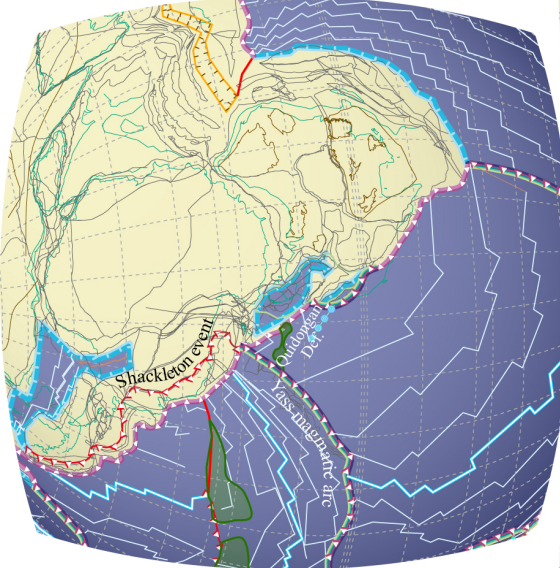

- 1) Pridoli

- o) Givetio-Frasnian
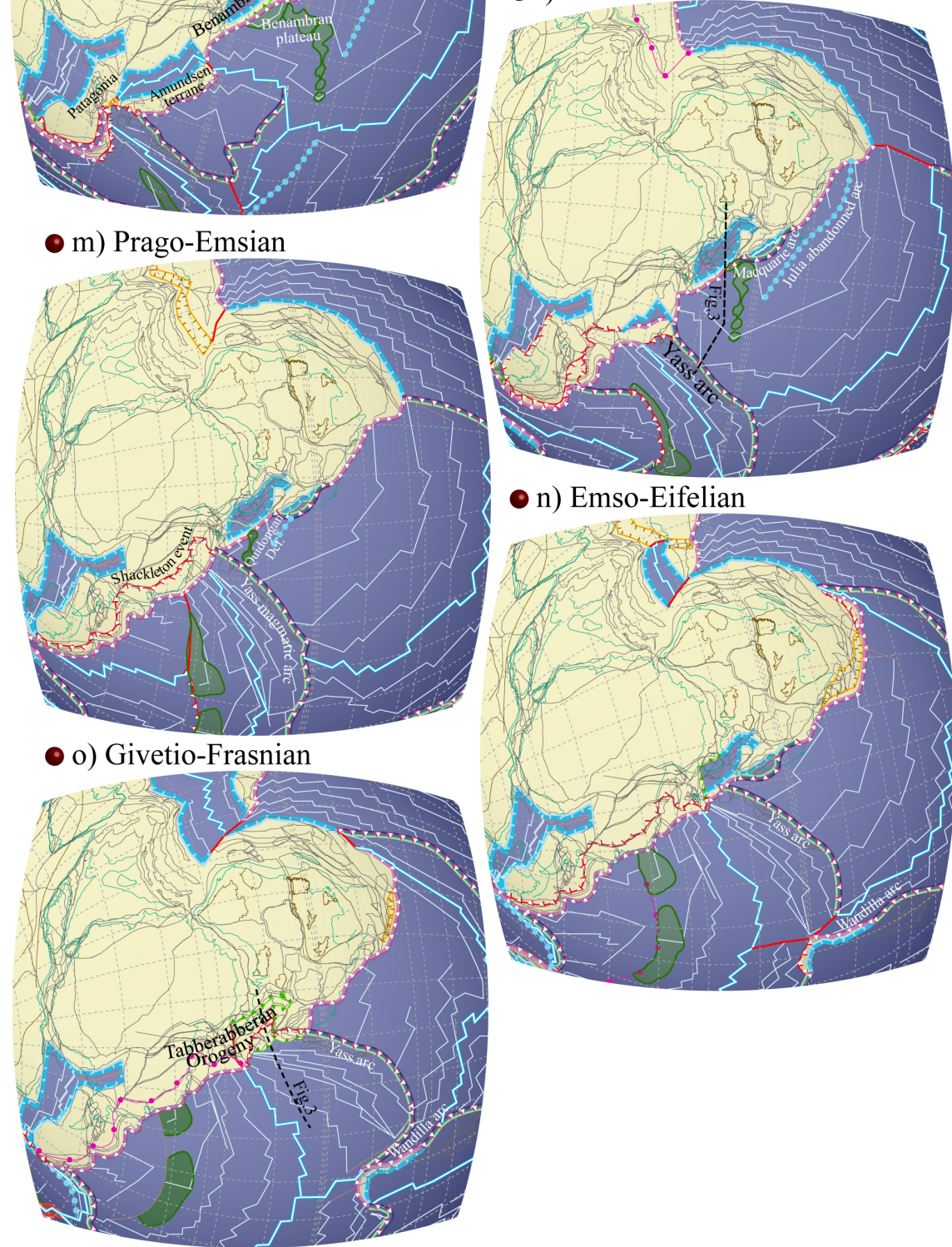

- n) Emso-Eifelian

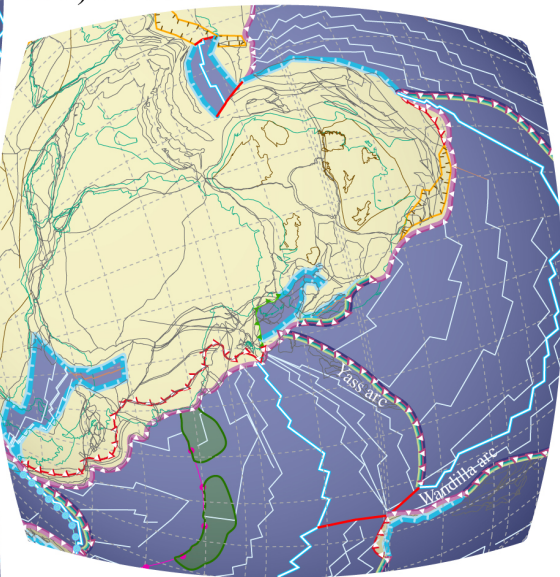


Figure 2. Cont.

- p) Frasnio-Famennian

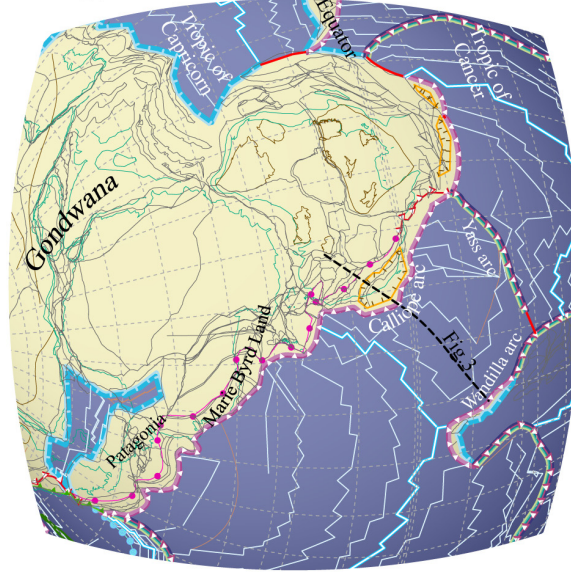

- q) Tournaisian

- r) Viseo-Serpukhovian
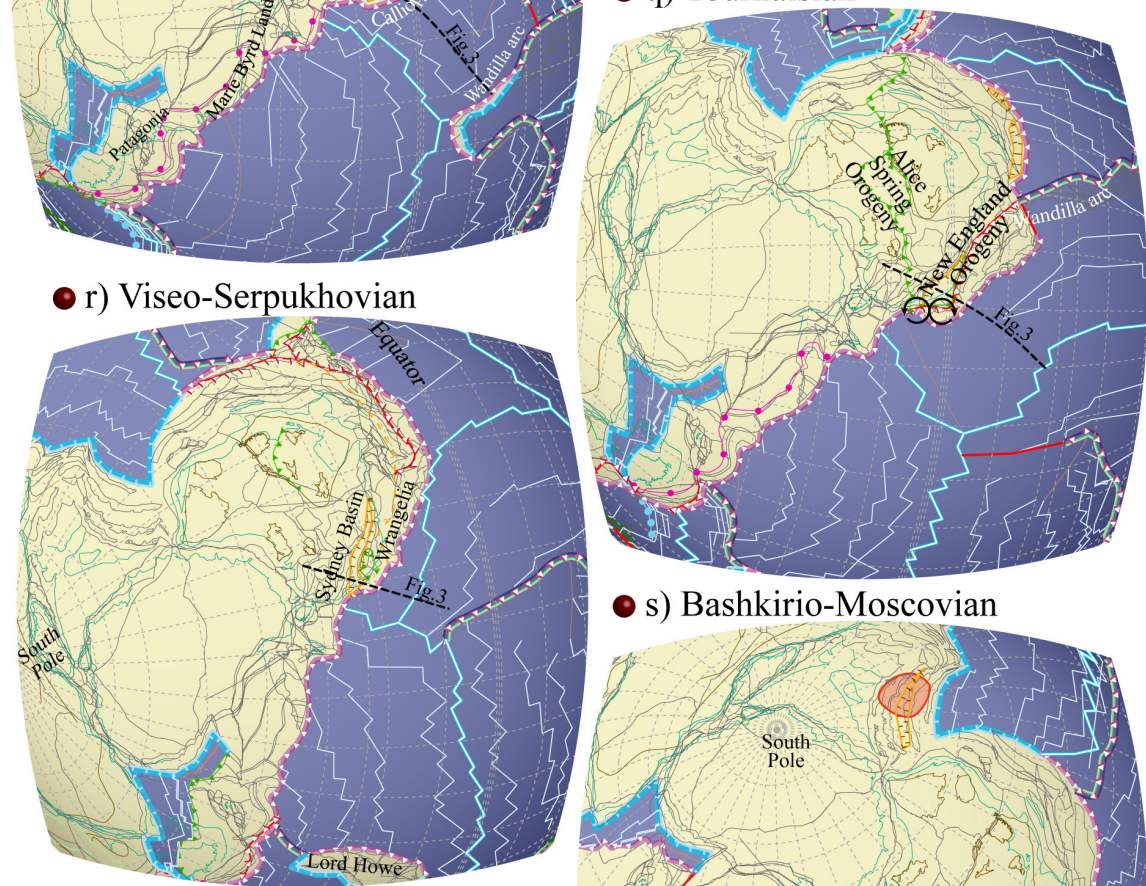

- s) Bashkirio-Moscovian

- t) Gzhelian
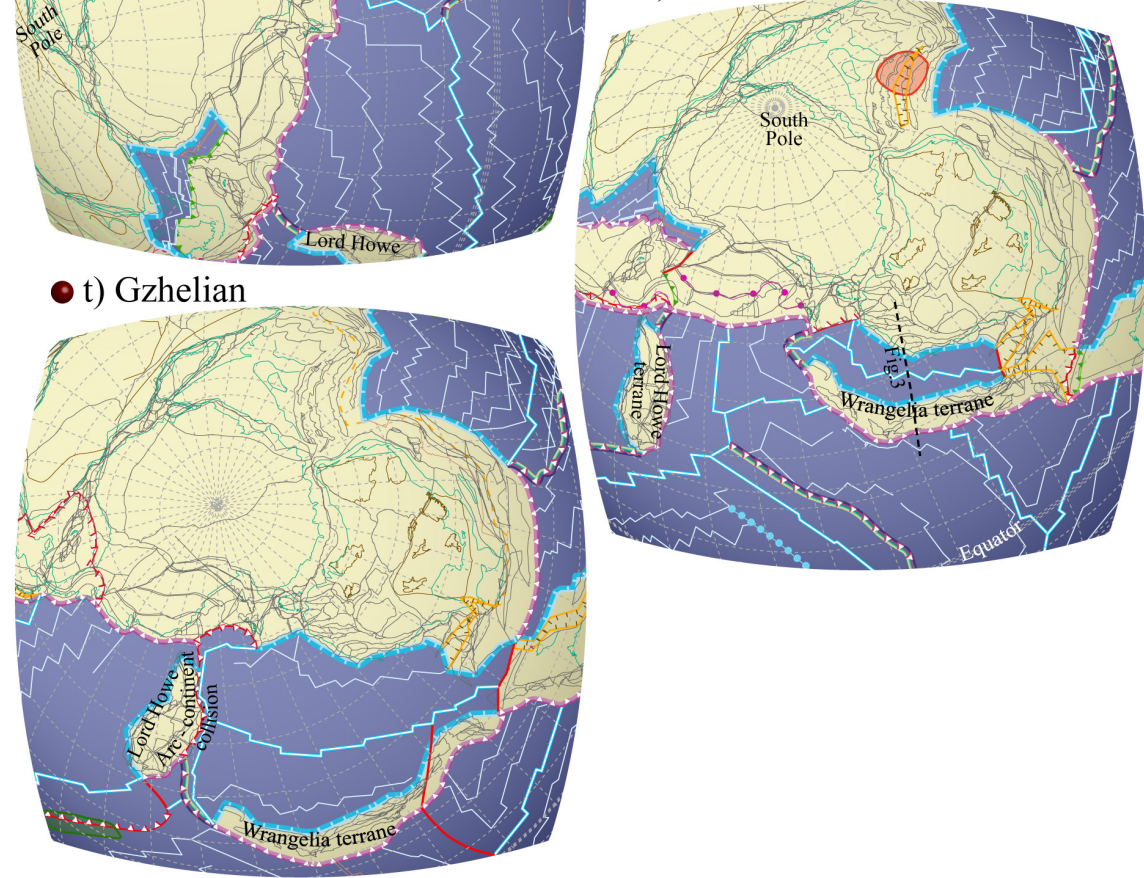
Figure 2. Cont.

○ u) Sakmario-Artinskian
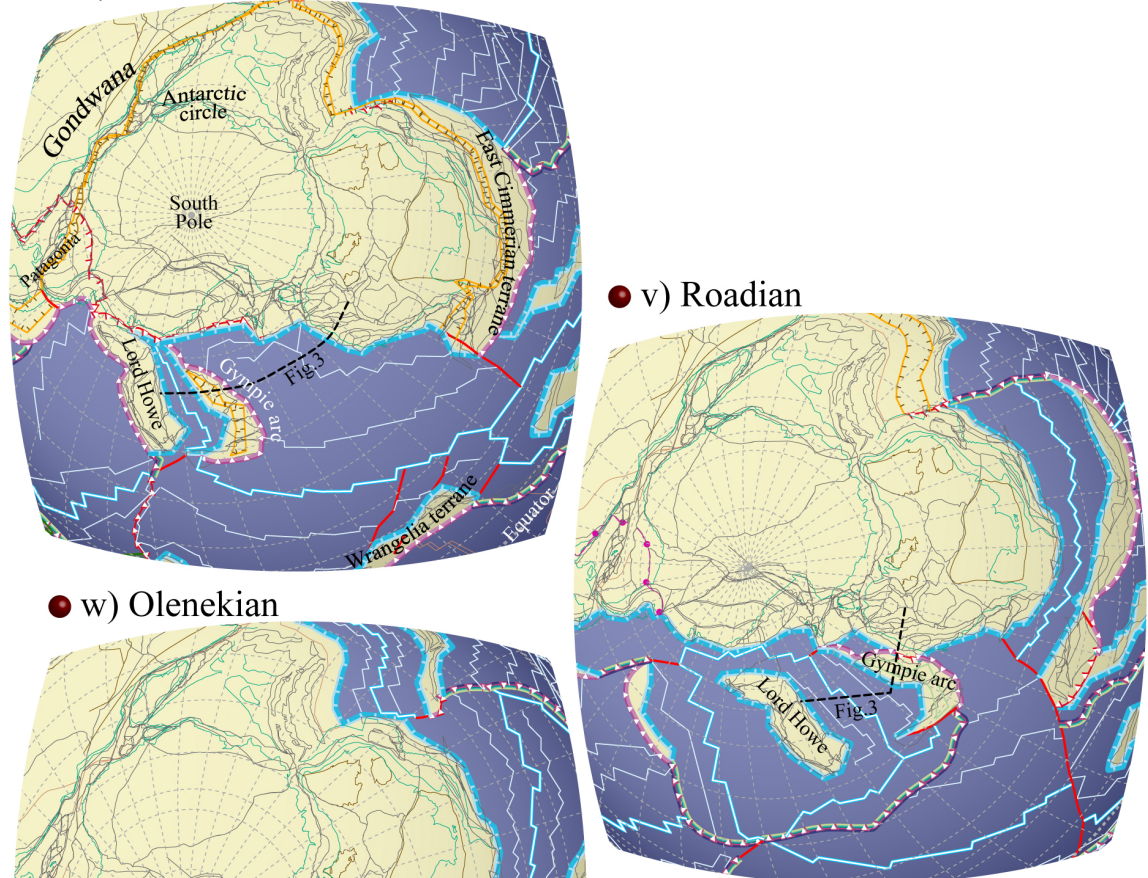

○ w) Olenekian

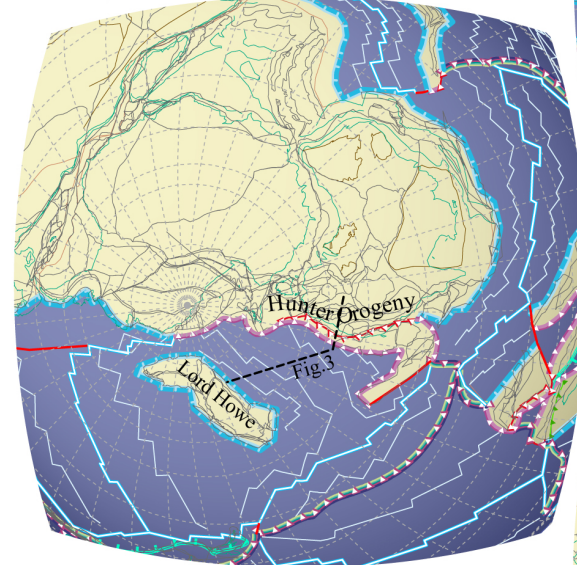

- x) Carnian

๑ y) Norio-Rhaetian
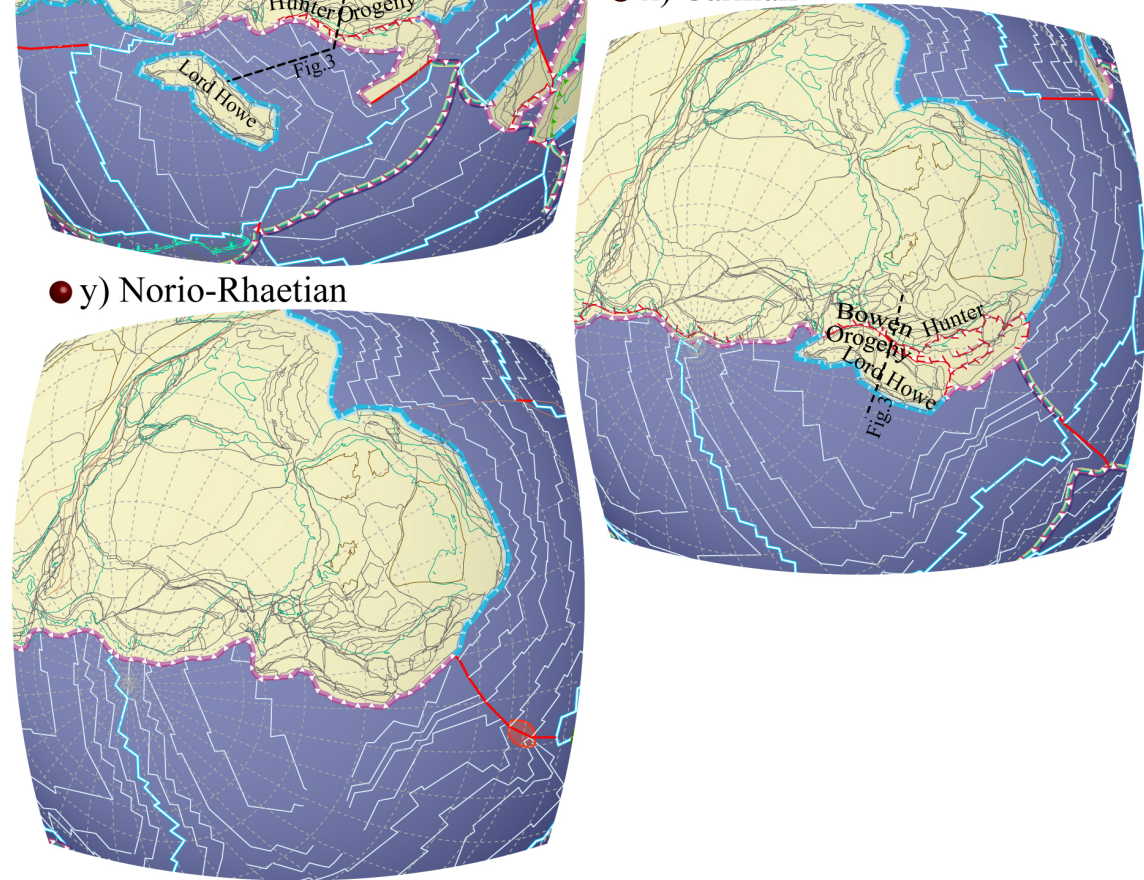

\subsection{The Delamerian Cycle (Figure 2a-h)}

In our reconstruction at $600 \mathrm{Ma}$, Australia-Antarctica faces Laurentia (Figure 2a), and both continents are located mainly according to palaeoclimatic and palaeomagnetic data. The eastern coast of Australia-Antarctica corresponds to a passive margin environment according to the Torrens Hinge Zone stratigraphy ([3] and references therein), which formed during the break-up of Rodinia (or Pannotia) ca. 750 Ma ago. Mafic igneous rocks (Koonenberry; Broken Hill area) east of the Curnamona Craton prove, however, that the passive margin turned into an active margin, with arc-related rocks dated at 
$526 \mathrm{Ma}$ that [35] related to a basin-and-range setting. The west coast of Laurentia appears to record rift setting, in particular as indicated by subsidence curves ([36]; see also [37]).

We propose accordingly that a large terrane - the Patagonia-Wagga terrane - rifted off Laurentia at (or just prior to) $600 \mathrm{Ma}$ (Figure 2a). However, a first magmatic arc - named herein Kayrunnera arc-detached from Laurentia, and collided diachronously with the Australia-Antarctica passive margin between 560 and $535 \mathrm{Ma}$ (Figure 2c,d), converting the Australian passive margin into active margin by subduction reversal (Figure 3; see also [29] for discussion about subduction reversal processes). Thus by $526 \mathrm{Ma}$, the Australia-Antarctica active margin is established. Slab roll-back induces cordillera collapse (corresponding thus to the basin-and-range setting of [35]), rifting and finally back-arc spreading as suggested by the $c a$. 7-8 km thick sediments and mafic rocks of MORB chemistry in the Kanmantoo Trough (Broken Hill area; [3] and references therein). We choose that time to create the Diamantina rifting, which we associate with large scale stretching of the Simpson, Cunnamulla, and Anakie GDUs (see below). We name "Bowers arc" the "new" magmatic arc detaching from Antarctica-Australia and migrating toward the Patagonia-Wagga terrane, the ribbon continent which has been detached from Laurentia. Meanwhile, Gondwana underwent its final assembly-and therefore came only into existence around $\sim 520 \mathrm{Ma}$ - through the Damara-Kuunga-Pinjarra orogenies (e.g., [38]). Arc-continent collision occured off-shore Gondwana between 510 and $500 \mathrm{Ma}$ (Figure 2g), and corresponds to the Delamerian Orogeny. Since the northern tail of the "Bowers arc" corresponds to intra-oceanic subduction in our model (plate boundary must be closed; Figure 2f), driving forces are considered large enough to trigger subduction propagation behind the accreted terrane after the Delamerian Orogeny. The oceanic plate — named Antoine plate in the model — is limited to the north by a transform fault (which allowed the terrane kinematics until accretion) and subduct beneath the newly created active margin. The collision (Delamerian Orogeny) also triggers the closure of the back-arc basin and finally a second collision (Figure 2h; Figure 3) - the Ross Orogeny-between the Patagonia-Wagga terrane and Gondwana. The hypothesis of a Delamerian Orogeny occurring "off-shore" Gondwana and followed shortly after by the Ross Orogeny is based on deformation ages clustering around $505 \mathrm{Ma}$ and around $485 \mathrm{Ma}$ in Australia (Broken Hill area, Mills, pers. com. [39]; [3] and references therein) and in Antarctica (Victoria Land; e.g., [40,41]), and the presence of two Cambrian volcanic belts predominantly observed in Victoria and in Tasmania. The change in directional trend of Cambrian Volcanics in Australia (from Stavely to Paka Tank GDUs) is explained by "oroclinal bending". Orocline formation was facilitated by lithospheric thinning during Diamantina rifting which permitted subsequent westward migration of the upper plate arc over the thinned lithosphere, driving crustal buckling about a vertical axis of rotation.

The Delamerian and Ross sutures are, therefore, close in space and time (i.e., potentially difficult to discriminate in the field), and run from the Pampian-Goias suture (see [42] and references therein) in South America (for the Ross suture only), along the Transantarctic Mountains in Antarctica, in western Tasmania, along both side of the Stavely, Lake Wintlow, and Kayrunnera GDUs, and along the Bygrave and Paka Tank GDUs in Australia (Figure 2h). 
Figure 3. Schematic cross-section (not to scale horizontally) depicting the general geodynamical evolution of the Australides. (a) Cross-section from Middle Ediacarian to Late Cambrian ("Delamerian Cycle"); (b) Cross-section from Early Ordovician to Mid Carboniferous ("Tabberabberan Cycle" and "Kanimblan Cycle"); (c) Cross-section from Mid Carboniferous to Late Triassic ("Hunter-Bowen SuperCycle").
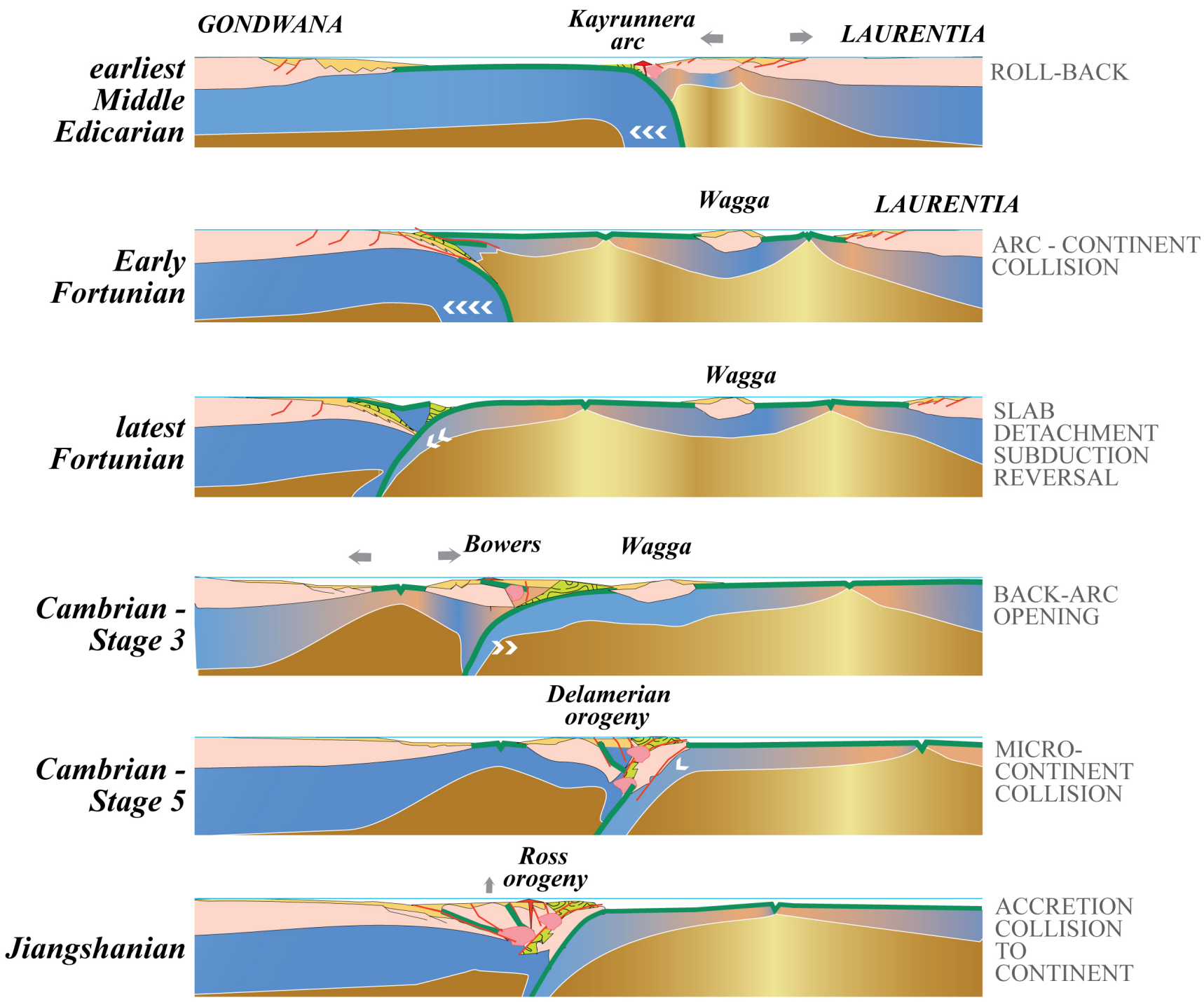

(a) 
Figure 3. Cont.

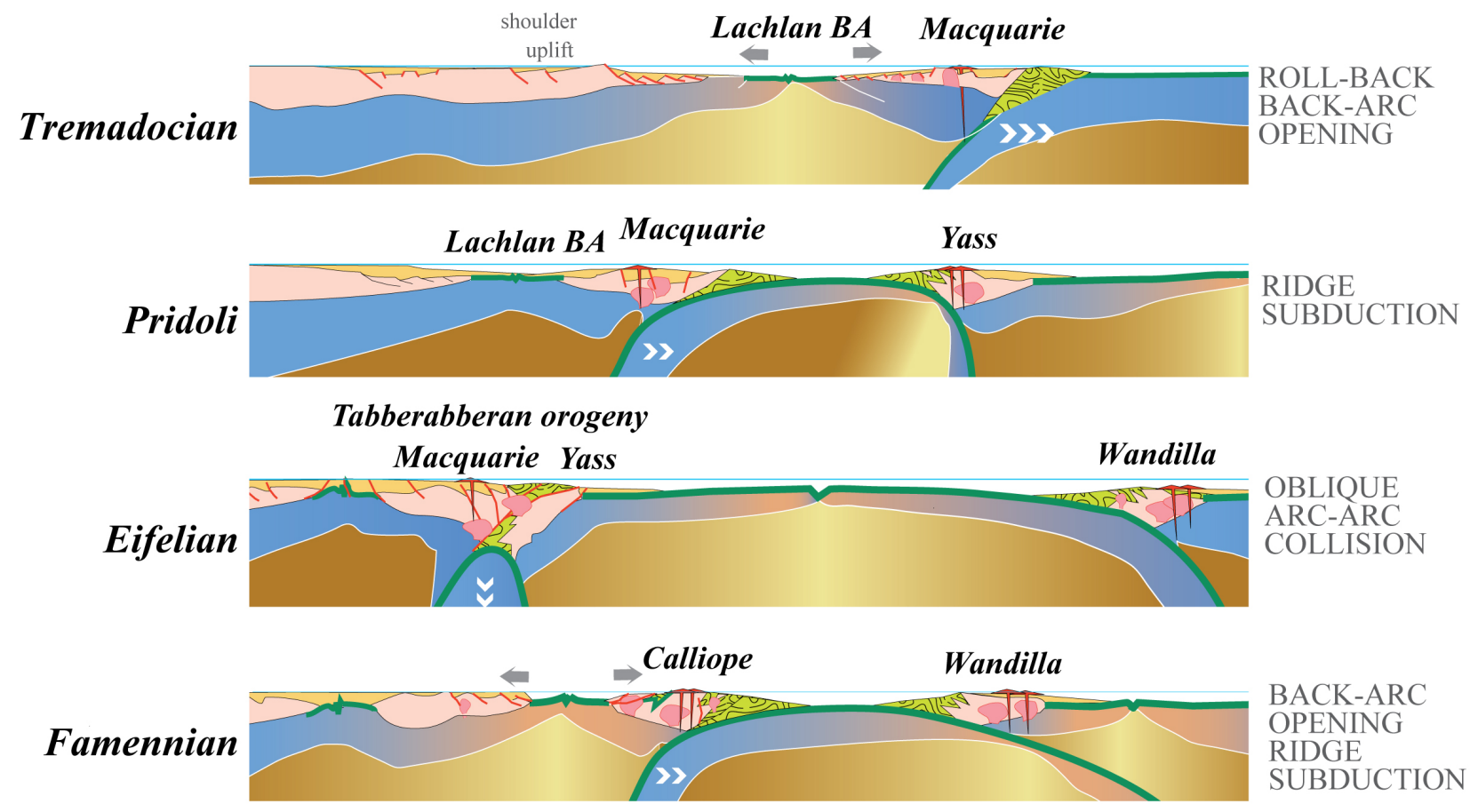

New England orogeny

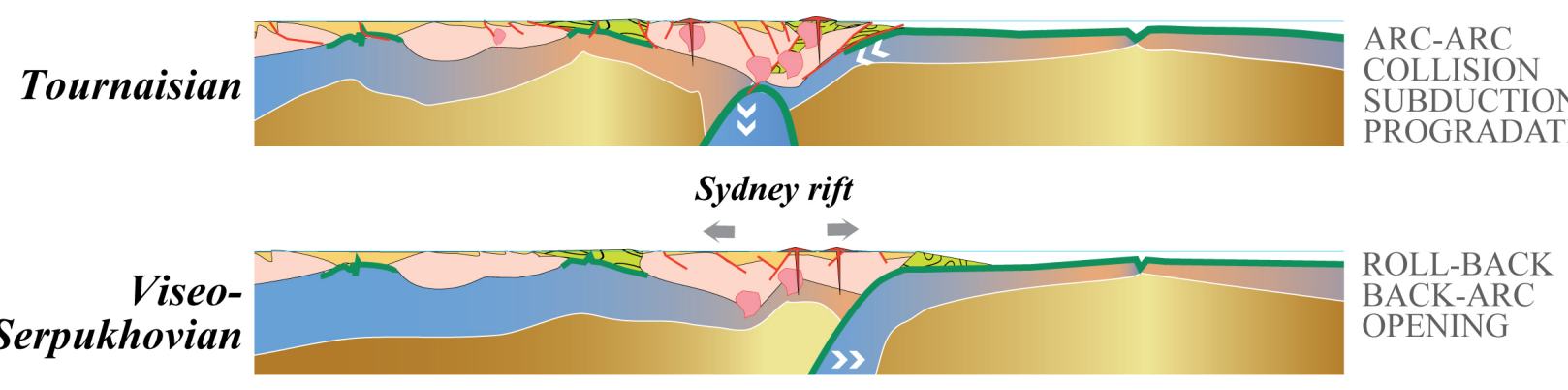

(b) 
Figure 3. Cont.

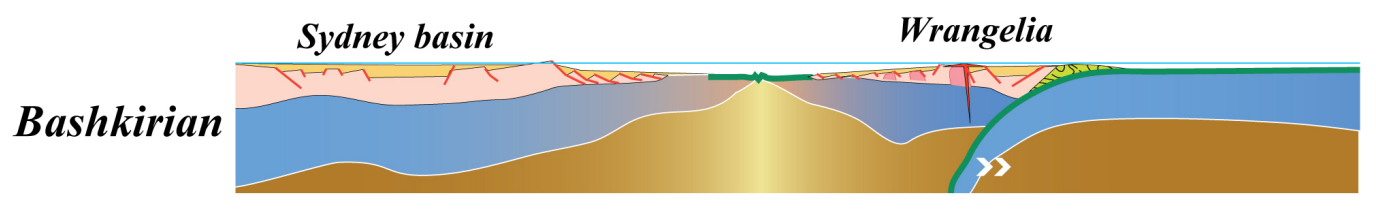

BACK-ARC

OPENING

RIDGE

SUBDUCTION
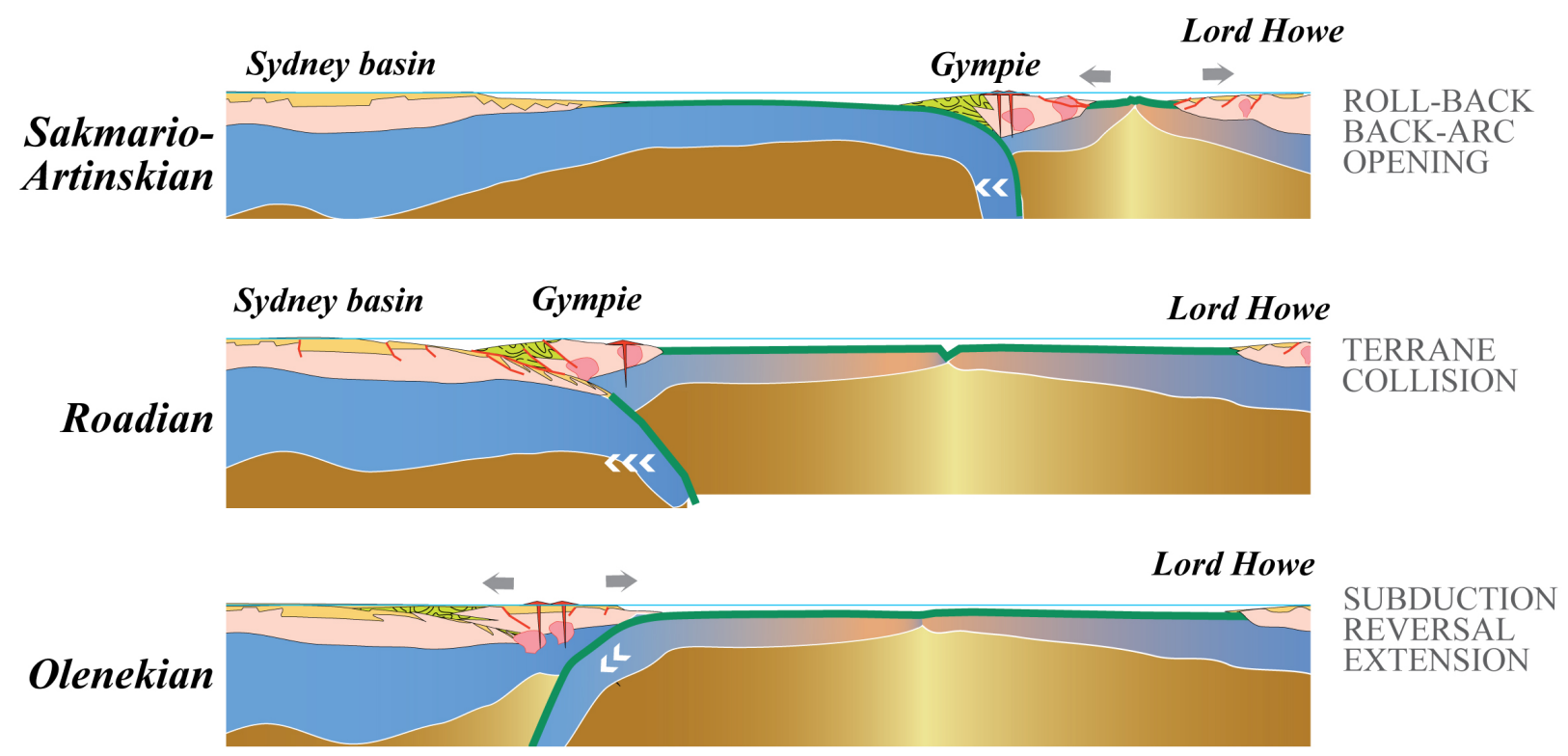

Bowen cordillera Lord Howe
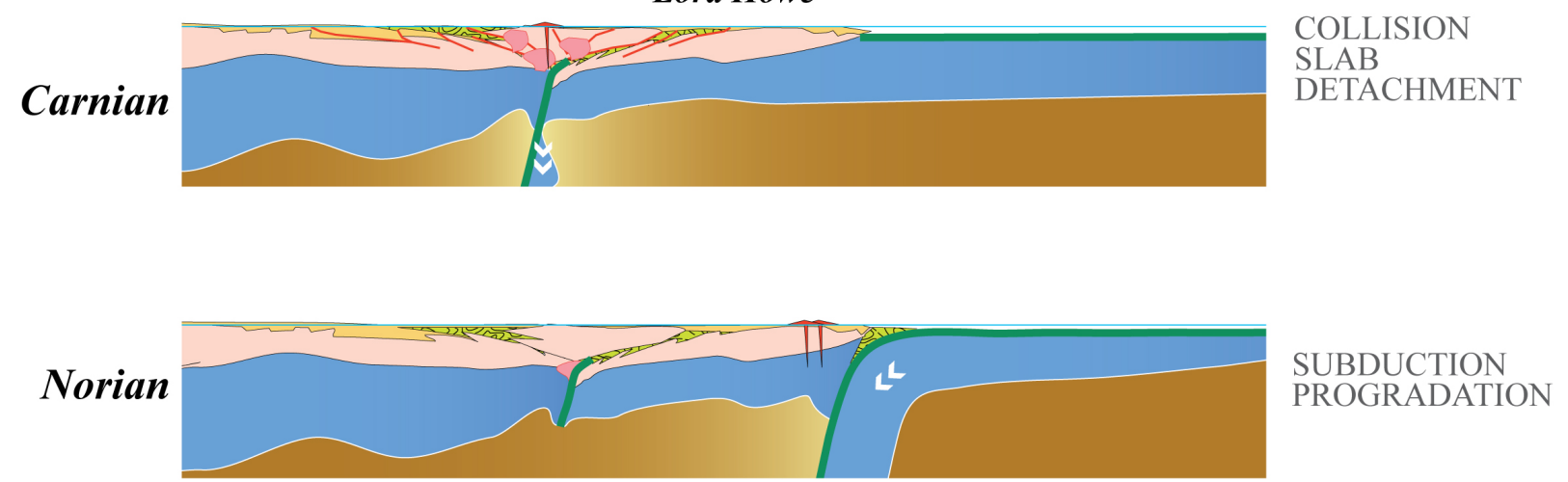

(c)

\subsection{The Lachlan Cycle (Figure $2 h-o$ )}

Subsequent to the terminal Ross collision, the Antoine oceanic plate was subject to north-south shortening. As a response, the above mentioned transform plate boundary failed, and a new intra-oceanic subduction zone developed, facilitated by the growth of a new plate - named the Julia plate. The new Delamerian-Ross cordillera collapses due to roll-back of the Antoine plate, and the Macquarie arc (sensu largo) detaches and forms the Lachlan back-arc basin (Figure 3). We assume that the basement of the Tabberabbera, Garnpung Lake, Mount Jake, Wagga-Omeo, and Parkes-Tumut GDUs is stretched but remains (partly?) continental in nature, whereas other GDUs have oceanic basement, in order to account for differences in sedimentary facies (see "shelves and troughs" in [3]). The Lachlan basin is viewed to some extent here as an equivalent of the present-day Tasman Sea or 
Scotia Sea, where strongly stretched continental fragments are left over from the arc during basin opening. Such a configuration can account for the necessary continental components, and the numerous geophysical and geochemical studies (e.g., [3] and references therein) showing that the basin crust is largely oceanic in nature (largely oceanic, but remaining of unclear nature in localized zones; see [21] for similar interpretation).

The southern extent of the Lachlan back-arc basin is limited by a strike-slip fault placed against the Robertson Bay GDU, in order to explain the position of the Proterozoic Surgeon Island granite, which has affinities with the Mawson craton (e.g., [40] and references therein; [41]). With such configuration, the granite could have been displaced along the fault during back-arc opening, and pulled away from the craton.

The basin is filled up with a thick pile (over $3 \mathrm{~km}$ locally; [43]) of turbiditic sediments derived from the Delamerian-Ross Orogen [44-46]. The thick turbiditic series may partly explain why the back-arc did not close later on (see below).

Hot spot magmatism is inferred to characterize off-shore Gondwana (Figure 2i). Ridge jump potentially associated with the hot-spot leads to splitting of the intra-oceanic magmatic arc (on the Julia tectonic plate). The Julia abandoned arc separates the Antoine Ocean from the Julia Sea (Figure 2j). The resulting oceanic plateau—named herein the Benambran plateau —and seamount chain are involved in an "arc-plateau collision" that we link to the Benambran Orogeny in the Rhuddanian (see [3] for a synthesis of the definitions of the Benambran Orogeny; Figure 2k). No data were found to support a model of rifting, migration and subsequent continent-continent collision of any terrane, which could correspond to that Benambran orogenic event. With an "arc-plateau collision" model, the southern end of the Macquarie arc (s.l.) is pinned, whereas the northern end splits and forms the Tumut and Cowra Troughs (Figure 21; [3] and references therein). The Macquarie arc (s.s.) is regarded as an intra-oceanic subduction-related arc, although it derives from a zone with a basement of continental nature in our reconstruction. A modern analogue of such configuration might be the Lau-Tonga-Kermadec arc (s.l.), which in part consists of an intra-oceanic arc, although it originates in our model from a continental area-the Lord Howe Rise [s.l.; stretched continental crust with shoal sedimentation, like the Wagga terrane (s.l.) in our model].

Following [42] (and references therein), terranes (in particular, Cuyana and Antofalla GDUs) are detached from Laurentia, and form an arc we refer to as the Yass magmatic arc, the tail of which corresponds to intra-oceanic subduction zone. Most of the GDUs from the eastern sub-province of the Lachlan Orogen belong to that arc, and move rather parallel to the Gondwana trench. However, oblique arc-continent collision explains the Shackleton Event in Antarctica ([47] and references therein; [40]). Local deformation events observed in the Lachlan Orogen (Quidongan Event, Bindi Event) are associated with arc-seamount or arc-abandoned arc collisions. Note that the Julia abandoned arc is well positioned to pin slab roll-back and stop or hamper the migration of the Macquarie arc further east (Figure $21-\mathrm{m}$ ).

The subsequent collision of the far travelled and well developed Yass arc with the Macquarie arc (s.l.) corresponds to the Tabberabberan Orogeny at ca. $380 \mathrm{Ma}$ (Figure 2o). The I-S line, a change in granitoidic rock chemistry ([48]; see also [49]), may reflect the two different origins of the arcs. In the model, we tentatively place the Rockeley-Gulgong GDU as part of the exotic (Yass) magmatic arc, although evidences are lacking. The Lachlan back-arc basin is shortened by thrusting, mimicking 
double (eastward and westward) subduction as postulated by [17] or [50], but the basin in-fill is probably too buoyant to permit total subduction. Note that exotic GDUs undergo large counter-clockwise rotations, as palaeomagnetically proposed by [2]. Note also that all GDUs on Figure 2o are regarded from now on as "continentalized" (i.e., as if they were continental in nature from now on).

\subsection{The New England Cycle (Figure $2 p-y$ )}

Following the Tabberabberan Orogeny (Figure 3), subduction reversal occurs resulting in subduction beneath an active Gondwana margin. The Calliope magmatic arc (e.g., [49]) develops and starts rifting off (Figure 2p). Whether the back-arc basin becomes fully oceanic or not is unclear, but stretching related to slab roll-back was probably strong (see below). Note that the model predicts the position of oceanic spreading axis off-shore Tasmania and Challenger Plateau. The buoyancy of the spreading axis might explain why the Calliope back-arc basin did not extend further south. Another arc comprising, in particular, GDUs from the Wandilla-Tableland area (at present-day located in the New England orogen) migrates toward the Gondwana margin (Figure 2p). The arc is a remnant attributable to subduction that occurred along the Laurentia margin (the story of which will be detailed elsewhere). We have no direct link between the GDUs encompassed in the Wandilla arc and Laurentia. However, those GDUs are exotic in origin ([3] and references therein), and given the global configuration in the model, the location of those GDUs in our Laurentian Wandilla arc, can be traced to Laurentia. The Wandilla arc collides with the Calliope arc ca. $350 \mathrm{Ma}$ ago ([3] and references therein). The Calliope back-arc must be strongly stretched or even oceanized at its southern end, because the overriding Wandilla arc can propagate inside and triggers oroclinal buckling of the New England Orogeny ([51] and discussion in [52]; [53,54]; see rounded arrows in Figure 2q).

Note that a "soft collision" occurs with South-East Asia $[55,56]$ north of Australia, and is linked to the coeval Alice Spring Orogeny in Central Australia, and the potential activation of the Lachlan Transverse Zone of [57-59].

Again, subduction reversal occurs after the arc-continent collision (New England Orogeny; Figure 2q), causing the collapse of the cordillera, and explaining the extension that formed the Sydney-Bowen-Gunnedah Basin System (indicated as Sydney basin s.l. at ca. $330 \mathrm{Ma}$ in Figure 2r). Within the Wandilla arc, we placed some GDUs now located in the Wrangellia area (North America). Wrangellia is an exotic terrane that crossed the Pacific. The reconstruction of the Pacific realm suggests a Gondwana origin for Wrangellia along the Australian margin [60-62]. The Sydney basin (s.l.) is regarded, therefore, as a rim basin, whereas rifting and sea-floor spreading occurred beyond (i.e., "east" of) the Wandilla-Tableland (s.l.) GDUs.

As the Wrangellia terrane drifted away from Gondwana, the Lord Howe terrane, which had previously detached from southern Laurentia, moves toward Australia (Figure 2s). The intra-oceanic subduction tail of the Wrangellia terrane collided with the Lord Howe terrane. Subduction reversal creates the Gympie magmatic arc ([49]; [3] and references therein), which then detaches from the Lord Howe terrane and moves toward Australia, while the Lord Howe terrane stays behind, as a "Madagascar-like microcontinent". We choose to derive the Gympie arc from the Lord Howe terrane, since the drift of Wrangellia resulted in a passive margin setting along Gondwana (Figure $2 \mathrm{u}$ ). Moreover, such configuration allows us to obtain the last two phases of the New England Cycle, 
namely the Hunter and Bowen orogenies. The Gympie arc is accreted diachronously from south to north between $c a$. $270 \mathrm{Ma}$ and $240 \mathrm{Ma}$, in agreement with basin infill recording and magmatic activity ([3] and references therein). After subduction reversal along the Gondwana margin, the Lord Howe terrane collided in the Carnian (Late Triassic deformation at $c a .233$ Ma after $[63,64]$ ).

\section{Conclusions}

Using strict plate tectonic rules and physically coherent hypotheses, the tectonic setting at $600 \mathrm{Ma}$ can be constructed (Figure 2y) so as to permit the exact configuration required at $200 \mathrm{Ma}$ (Figure 1).

The development of a fully global geodynamical model (Figure 2) rooted in the available geological data (Figure 3) allowed us to re-appraise the Palaeozoic evolution of the Australides. Contrary to many reconstructions proposed for the same region, numerous orogenic events now observed in Australia are inferred to have occurred off-shore Gondwana. All terranes of the Australides are regarded as exotic in nature at some time, which has some important implications for the apparent polar wander path deduced from palaeomagnetism, in particular. Constraints on older reconstructions $(\geq 550-600 \mathrm{Ma})$, however, are rather poor, and the model needs to be refined, in particular for those periods.

\section{Acknowledgments}

We gratefully thank Cyril Hochard, Laurent Thum, Caroline Wilhem, Claire Gracia-Garay, Kennet Flores-Reyes, and all members of the Stampfli's working group for sharing their data, ideas, and time with us. The Swiss National Fund (SNF) and SHELL equally acknowledged for funding the present work. The work was carried out as part of the research program of the University of Lausanne on the "Stampfli geodynamic model", which is now owned by Neftex Petroleum Consultants Ltd. and attached to the "Neftex Earth Model". We are grateful to Neftex for allowing us to present in this publication some details from the geodynamic model obtained prior to 28 February 2010 . We sincerely thank Stephen Johnston and two anonymous reviewers for their thorough and constructive comments.

\section{Declare}

Commercial re-use of the data and images copyright to Neftex Petroleum Consultants Ltd. is prohibited (Figures 1 and 2).

\section{References}

1. Vaughan, A.; Leat, P.; Pankurst, R. Terrane processes at the margin of Gondwana: Introduction. Geological Society London Special Publications 2005, 246, 1-22.

2. Vérard, C. Palaeozoic Palaeomagnetism of Southeastern Australia: Implications for the APW Path of Gondwana. Ph.D. Thesis, Ludwig-Maximilians-Universität München, Munich, Germany, 2 June 2004.

3. Glen, R. The Tasmanides of eastern Australia. Geological Society London Special Publications 2005, 246, 23-96.

4. Vérard, C.; Stampfli, G.M. Geodynamic reconstructions of the Australides-2: Mesozoic-Cainozoic. Geosciences 2013, 3, in press. 
5. Stump, E.; White, A.; Borg, S. Reconstruction of Australia and Antarctica: Evidence from granites and recent mapping. Earth Planet. Sci. Lett. 1986, 79, 348-360.

6. Borg, S.; de Paolo, D. A tectonic model of the Antarctic Gondwana margin with implications for southeastern Australia: Isotopic and geochemical evidence. Tectonophysics 1991, 196, 339-358.

7. Cooper, R.; Tulloch, A. Early Palaeozoic terranes in New Zealand and their relationship to the Lachlan Fold Belt. Tectonophysics 1992, 214, 129-144.

8. Gibson, G. Medium-high-pressure metamorphic rocks of the Tuhua Orogen, western New Zealand, as lower crustal analogues of the Lachlan Fold Belt, SE Australia. Tectonophysics 1992, 214, 145-157.

9. Glen, R.; Dallmeyer, R.; Black, L. Isotopic dating of basin inversion-The Palaeozoic Cobar Basin, Lachlan Orogen, Australia. Tectonophysics 1992, 214, 249-268.

10. Glen, R.; Scheibner, E.; van den Berg, A. Paleozoic intraplate escape tectonics in Gondwanaland and major strike-slip duplication in the Lachlan Orogen of southeastern Australia. Geology 1992, 20, 795-798.

11. Sutherland, R. Basement geology and tectonic development of the greater New Zealand region: An interpretation from regional magnetic data. Tectonophysics 1999, 308, 341-362.

12. Veevers, J. Phanerozoic Earth History of Australia; Clarendon Press: Oxford, UK, 1984.

13. Veevers, J. Billion-Year Earth History of Australia and Neighbours in Gondwanaland; GEMOC Press: Sydney, Australia, 2000.

14. Veevers, J. Atlas of Billion-Year Earth History of Australia and Neighbours in Gondwanaland; GEMOC Press: Sydney, Australia, 2001.

15. Veevers, J. Gondwanaland from 650-500 Ma assembly through $320 \mathrm{Ma}$ merger in Pangea to 185-100 Ma breakup: Supercontinental tectonics via stratigraphy and radiometric dating. Earth Sci. Rev. 2004, 68, 1-132.

16. Veevers, J. Pan-African is Pan-Gondwanaland: Oblique convergence drives rotation during 650-500 Ma assembly. Geology 2010, 31, 1-132.

17. Gray, D.; Foster, D. Orogenic concepts-Application and definition: Lachlan Fold Belt, eastern Australia. Am. J. Sci. 1997, 297, 859-891.

18. Gray, D.; Foster, D.; Bierlein, F. Geodynamics and metallogeny of the Lachlan Orogen. Austr. J. Earth Sci. 2002, 49, 1041-1056.

19. Fergusson, C.; Coney, P. Convergence and intraplate deformation in the Lachlan Fold Belt of southeastern Australia. Tectonophysics 1992, 214, 417-439.

20. Collins, W.; Vernon, R. Palaeozoic arc growth, deformation and migration across the Lachlan Fold Belt, southeastern Australia. Tectonophysics 1992, 214, 381-400.

21. Foster, D.; Gray, D.; Spaggiari, C.; Kamenov, G.; Bierlein, F. Palaeozoic Lachlan Orogen, Australia; Accretion and construction of continental crust in a marginal ocean setting: Isotopic evidence from cambrian metavolcanic rocks. Geological Society London Special Publications 2009, 318, 329-349.

22. Stampfli, G.; Borel, G. A plate tectonic model for the Paleozoic and Mesozoic constrained by dynamic plate boundaries and restored synthetic oceanic isochrons. Earth Planet. Sci. Lett. 2002, 196, 17-33. 
23. Stampfli, G.; Borel, G. The TRANSMED transects in space and time: Constraints on the Paleotectonic evolution of the Mediterranean domain. In The TRANSMED Atlas: The Mediterranean Region from Crust to Mantle; Cavazza, W., Roure, F., Spakman, W., Stampfli, G., Ziegler, P., Eds.; Springer Verlag: Berlin, Germany, 2004; pp. 53-80.

24. Hochard, C. GIS and Geodatabases Application to Global Scale Plate Tectonic Modelling. Ph.D. Thesis, University of Lausanne, Lausanne, Switzerland, 18 April 2008.

25. Stampfli, G.; Hochard, C.; Vérard, C.; Wilhem, C.; von Raumer, J. The formation of Pangæa. Tectonophysics 2013, 593, 1-19.

26. Müller, R.; Roest, W.; Royer, J.-Y.; Gahagan, L.; Sclater, J. Digital isochrones of the world's ocean floor. J. Geophys. Res. 1997, 102, 3211-3214.

27. Müller, D.; Sdrolias, M.; Gaina, C.; Roest, R. Age, spreading rates and spreading symmetry of the world's ocean crust. Geochem. Geophys. Geosyst. 2008, 9, Q04006:1-Q04006:19.

28. De Mets, C.; Gordon, R.; Argus, D.; Stein, S. Effect of recent revisions to the geomagnetic reversal time scale on estimates of current plate motions. Geophys. Res. Lett. 1994, 21, 2191-2194.

29. Baes, M.; Govers, R.; Wortel, R. Switching between alternative responses of the lithosphere to continental collision. Geophys. J. Int. 2011, 187, 1151-1174.

30. Hafkenscheid, E.; Wortel, R.; Spakman, W. Subduction history of the Tethyan region derived from seismic tomography and tectonic reconstructions. J. Geophys. Res. 2006, 111, B08401.

31. Webb, P. Mantle Circulation Models: Constraining Mantle Dynamics, Testing Plate Motion History and Calculating Dynamic Topography. Ph.D. Thesis, University of Cardiff, Cardiff, UK, 1 August 2012.

32. Torsvik, T.; van der Voo, R. Refining Gondwana and Pangea palaeogeography: Estimates of Phanerozoic non-dipole (octupole) fields. Geophys. J. Int. 2002, 151, 771-794.

33. Amante, C.; Eakins, B. ETOPO1-1 Arc-minute Global Relief Model: Procedures, Data Sources and Analysis; NOAA Technical Memorandum NESDIS NGDC-24; National Geophysical Data Center, Marine Geology and Geophysics Division: Boulder, CO, USA, 2009.

34. International Commission on Stratigraphy. International Chronostratigraphic Chart, Version 2013/01. Available online: http://www.stratigraphy.org/ICSchart/ChronostratChart2013-01.pdf (accessed on 28 May 2013).

35. Crawford, A.; Stevens, B.; Fanning, M. Geochemistry and tectonic setting of some Neoproterozoic and Early Cambrian volcanics in western New South Wales. Austr. J. Earth Sci. 1997, 44, 831-852.

36. Wright, G.; McMechan, M.; Potter, D. Structure and Architecture of the Western Canada BasinChapter 3. Online Version of the Geological Atlas of the Western Canada Sedimentary Basin (WCSB), 2008. Available online: http://www.ags.gov.ab.ca/publications/wcsb_atlas/atlas.html (accessed on 23 May 2013).

37. Burchfiel, B.; Lipman, P.; Zoback, M. The Cordilleran Orogen: Conterminous U.S. The Geology of North America: Volume G-3; Geological Society of America: Boulder, CO, USA, 1992.

38. Fitzsimons, I. Proterozoic basement provinces of southern and southwestern Australia, and their Correlation with Antarctica. Geological Society London Special Publications 2003, 206, 93-130. 
39. Mills, K.J. Geological Survey of New South Wales, Broken Hill, Australia. Personal communication, 2 April 2008.

40. Stump, E. The Ross Orogen of the Transantarctic Mountains; Cambridge University Press: Cambridge, UK, 1995.

41. Tessensohn, F.; Henjes-Kunst, F. Northern Victoria land terranes, Antarctica: Far-travelled or local products? Geological Society London Special Publications 2005, 246, 275-291.

42. Rapalini, A. The Accretionary history of the southern South America from the latest Proterozoic to the late Palaeozoic: Some palaeomagnetic constraints. Geological Society London Special Publications 2005, 246, 305-328.

43. Van den Berg, A.; Stewart, I. Ordovician terranes of the southeastern Lachlan Fold Belt: Statigraphy, structure and palaeogeographic reconstruction. Tectonophysics 1992, 214, 159-176.

44. Fergusson, C.; Tye, S. Provenance of early Palaeozoic sandstones, southeastern Australia, Part 1: Vertical changes through the Bengal fan-type deposit. Sediment. Geol. 1999, 125, 135-151.

45. Colquoun, G.; Fergusson, C.; Tye, S. Provenance of early Palaeozoic sandstones, southeastern Australia, Part 2: Cratonic to arc switching. Sediment. Geol. 1999, 125, 153-163.

46. Van den Berg, A.; Willman, C.; Maher, S. The Tasman Fold Belt System in Victoria: Geology and Mineralisation of Proterozoic to Carboniferous Rocks; Geological Survey of Victoria Special Publication; Geological Survey: Victoria, Australia, 2000.

47. Tingey, R. The Geology of Antarctica; Oxford Monographs on Geology and Geophysics 17; Oxford University Press: Oxford, UK, 1991.

48. White, S.; Williams, I.; Chappell, B. Berridale 1:100’000 Geological Sheet 8625; Geological Survey of New South Wales: Sydney, Austraila, 1976.

49. Scheibner, E.; Basden, H. Geology of New South Wales-Synthesis. Volume 1 Structural Framework; Geological Survey of New South Wales: Sydney, Australia, 1996.

50. Spaggiari, C.; Gray, D.; Foster, D. Ophiolite accretion in the Lachlan Orogen, Southeastern Australia. J. Struct. Geol. 2004, 26, 87-112.

51. Klootwijk, C. Carboniferous palaeomagnetism of the Rocky Creek Block, northern Tamworth Belt, and the New England pole path. Austr. J. Earth Sci. 2002, 49, 375-405.

52. Schmidt, P.; McElhinny, M.; Klootwijk, C. Discussion and reply: Carboniferous palaeomagnetism of the Rocky Creek Block, northern Tamworth Belt, and the New England pole path. Austr. J. Earth Sci. 2003, 50, 129-135.

53. Geeve, R.; Schmidt, P.; Roberts, J. Paleomagnetic results indicate pre-Permian counter-clockwise rotation of the southern Tamworth Belt, southern New England Orogen, Australia. J. Geophys. Res. 2002, 107, EPM.4.1-EPM.4.16.

54. Li, P.; Rosenbaum, G.; Donchak, P. Structural evolution of the Texas Orocline, eastern Australia. Gondwana Res. 2012, 22, 279-289.

55. Ferrari, O.; Hochard, C.; Stampfli, G. An alternative plate tectonic model for the Palaeozoic-Early Mesozoic Palaeotethyan evolution of Southeast Asia (Northern Thailand-Burma. Tectonophysics 2008, 451, 346-365.

56. Wilhem, C. Plate Tectonics of the Altaids. Ph.D. Thesis, University of Lausanne, Lausanne, Switzerland, 11 May 2010. 
57. Glen, R.; Wyborn, D. Inferred thrust imbrication, deformation gradients and the Lachlan transverse zone in the eastern belt of the Lachlan Orogen. Austr. J. Earth Sci. 1997, 44, 49-68.

58. Glen, R.; Walsche, J. Cross-structures in the Lachlan Orogen: The Lachlan Transverse Zone example. Austr. J. Earth Sci. 1999, 46, 641-658.

59. Vérard, C.; Glen, R. Magnetic fabrics of Palaeozoic rocks across the Lachlan Transverse Zone from eastern New South Wales. Austr. J. Earth Sci. 2008, 55, 1037-1048.

60. Johnston, S.; Borel, G. The odyssey of the Cache Creek terrane, Canadian Cordillera: Implications for accretionary orogens, tectonic setting of Panthalassa, the Pacific superwell, and break-up of Pangea. Earth Planet. Sci. Lett. 2007, 253, 415-428.

61. Chablais, J.; Martini, R.; Kobayashi, F.; Stampfli, G. Upper Triassic foraminifers from Japanese Panthalassan mid-oceanic carbonate buildups (Sambosan Accretionary Complex): palaeobiogeographic implications. Micropaleontology 2011, 57, 93-124.

62. Flores-Reyes, K. Mesozoic Oceanic Terranes of Southern Central America-Geology, Geochemistry and Geodynamics. Ph.D. Thesis, University of Lausanne, Lausanne, Switzerland, 18 December 2009.

63. Korsch, R.; Wake-Dyster, K.; Johnstone, D. Seismic imaging of Late Palaeozoic-Early Mesozoic extensional and contractional structures in the Bowen and Surat basins, eastern Australia. Tectonophysics 1992, 215, 273-294.

64. Korsch, R.; Wake-Dyster, K.; Johnstone, D. The Gunnedah Basin-New England Orogen deep seismic reflection profile: Implications for New England tectonics. In Abstract Volume, Conference on the New England Orogen, Eastern Australia; Flood, P., Aitchison, J., Eds.; University of New England: Armidale, Australia, 1993; pp. 85-100.

(C) 2013 by the authors; licensee MDPI, Basel, Switzerland. This article is an open access article distributed under the terms and conditions of the Creative Commons Attribution license (http://creativecommons.org/licenses/by/3.0/). 